\title{
The filter bag versus the conventional filtration technique for the determination of crude fibre and Van Soest cell wall constituents*
}

\author{
B.G. D'heer', J.L. De Boever, J.M. Vanacker and Ch.V. Boucqué
}

\author{
Department Animal Nutrition and Husbandry, \\ Agricultural Research Centre - Ghent \\ Scheldew'eg 68, B-9090 Melle-Gontrode, Belgium
}

(Received 4 August 1999; accepted 15 July 2000)

\begin{abstract}
To determine crude fibre (CF), NDF, ADF and ADL, the conventional technique (CT), using filter crucibles, was compared with the filter bag technique (FBT). The mean CF content of 56 forages and concentrates was slightly, but significantly lower $(\mathrm{P}<0.001)$ with FBT than with CT (144 vs $138 \mathrm{~g} \mathrm{~kg}^{-1} \mathrm{DM}$ ). The two techniques were highly correlated (0.996) and FBT had better repeatability. The mean CF content of 28 faeces samples was similar for both techniques, but repeatability with FBT was worse. The latter was greatly improved by reducing the sample weight from 1 to $0.5 \mathrm{~g}$. For NDF a comparative study was done with 10 non-starchy feeds, 14 starchy feeds, as well as with 28 feed residues from in sacco incubations. To obtain similar values with FBT as with $\mathrm{CT}$, it is recommended to use a sample weight of $0.5 \mathrm{~g}$ and to add for all starch containing samples $12 \mathrm{~m}$ ! of an $\alpha$-amylase solution, equally spread over the digestion and the first two rinsing periods. For ADF of 11 feeds the correlation between the two techniques improved from 0.993 to 0.997 when 0.5 instead of $1.0 \mathrm{~g}$ sample was incubated and repeatability was clearly better for the FBT. For ADL of 12 feeds, after sequential analysis of NDF and ADF, the FBT showed excellent precision and no significant difference with the CT.
\end{abstract}

KEY WORDS: crude fibre, NDF, ADF, sequential analysis, filter bag technique

\footnotetext{
* Communication No. 1083 of the Department

1 Corresponding author
} 


\section{INTRODUCTION}

For almost two hundred years, crude fibre (CF), and more recently, the Van Soest cell wall parameters, NDF, ADF and lignin, have been used to characterise ruminant feeds. Moreover, they are common parameters in practical feed cvaluation for the prediction of voluntary intake (Van Soest et al., 1978; De Brabander et al., 1987; Jung and Allen, 1995), digestibility and energy value (De Boever et al., 1996, 1997) as well as the physical structure content (De Brabander et al., 1996). However, these parameters are considered more or less arbitrary because their procedure is rather empirical and no primary fibre standard is available. To ensure a high reproducibility within and between laboratories, an optimal standardisation of the procedures is therefore of paramount importance, particularly with regard to the filtration step, which is generally accepted as the most critical factor in the gravimetric determination of fibre in feeds and facces.

At present, $\mathrm{CF}$ as well as the Van Socst cell wall constituents are commonly determined using an extraction unit with vacuum-assisted filter crucibles, which allows a better standardisation than the original manual method using Berzelius beakers. Nevertheless, this semi-automatic system now generally referred as the conventional technique (CT), remains rather laborious and less repeatable due to the individual digestion of the samples and the hand-controlled filtration. To solve these problems, ANKOM Technology Corporation (New York, USA) recently developed a filter bag technique (FBT). With this technique up to 24 samples enclosed in fabric filter bags, can be digested simultaneously in the extraction solution in a closed vessel with temperature control. Because of the uniformity of the batch-treatment and the automation of the sensitive filtration, the FBT is claimed to be very precise (Komarek, 1993).

Komarck et al. found no significant differences between the CT and the FBT for determining NDF (1994b), ADF (1994a) and CF (1996) in some 20 samples of forages and concentrates. From these studies a correlation coefficient between both techniques of more than 0.99 for all three fibre parameters could be calculated. In more independent comparative studies however, those excellent results could not be fully repeated. Analysing CF in fceds, faeces and digesta, Kuhla (1998) found significant higher values $(\mathrm{P}<0.05)$ with the FBT than with the CT (191 vs $176 \mathrm{~g} \mathrm{~kg}^{-1} \mathrm{DM}$ ) and no better repeatability. Spanghero et al. (1997) found a close relationship between the two techniques for NDF and ADF with 28 forages and for ADF with 15 starchy feeds, but erroneously high NDF values with FBT for the latter, despite the use of $\alpha$-amylase.

Because of these conflicting results, the aim of this study was to compare the two techniques under similar conditions for determining CF, NDF and ADF in a wide variety of feeds as well as CF in faeces. The comparison also concerned the determination of ADF and ADL in sequential analysis. Where necessary, the FBT procedure was modified to obtain a better accuracy and repeatability. 


\section{MATERIAL AND METHODS}

The CT was carried out with the Fibertec apparatus (System I, Tecator, Höganäs, Sweden), equipped with six filtration crucibles. For the determination of $\mathrm{CF}$ and Van Soest ccll wall constituents, crucibles with porosity $\mathrm{P} 2(40-90 \mu \mathrm{m})$ and P1 $(90-150 \mu \mathrm{m})$ were used, respectively. The FBT was done with the Fiber Analyzer (ANKOM ${ }^{220}$, ANKOM Technology Corporation, New York, USA) using F56 filter bags. With the FBT, a blank bag was incorporated in each run, which allowed to derive a mean factor per fibre parameter to correct for the ash content of the bag as well as for its loss of weight during digestion.

Feed and faeces samples were oven-dried $\left( \pm 65^{\circ} \mathrm{C}\right)$ and ground with a Brabender mill to pass a $1 \mathrm{~mm}$ screen. All analyses were carried out in duplicate but in separate runs. For differences between duplicates of more than $5 \%$, it was decided to do a replication.

\section{Crude fibre}

CF was determined on 56 samples of feed and 28 samples of faeces. The fecd samples were of diverse nature: 21 forages [maize silage (13), grass silage (5), ensiled brewers' grains, grass hay, wheat straw], 14 raw materials [formaldehyde treated soyabean meal (3), soyabean meal (2), malt sprouts (2), coconut expeller, dehydrated lucerne meal, dehydrated sugar beet pulp, extracted rape seed, rice bran, soyabeans, wheat bran], 11 ruminant compound fecds and 10 pig feeds. The faeces samples originated from digestion trials with bulls (8), cows (8), sheep (7) and pigs (5).

For the CT, guideline L344/36 (EC, 1992) was followed, which involves successive digestion of the sample in $0.13 \mathrm{M} \mathrm{H}_{2} \mathrm{SO}_{4}$ and $0.23 \mathrm{M} \mathrm{KOH}$, and the gravimetric determination of the organic residue. Although a specific procedure was prescribed by ANKOM (Komarek et al., 1996), the instructions of the EC-method were followed as much as possible for evaluating the FBT. One gramme samples were weighed into pre-dried (overnight at $\pm 65^{\circ} \mathrm{C}$ ) and pre-tared filter bags. To ensure an optimum digestion, the material was uniformly distributed in the bag. Samples with more than $100 \mathrm{~g}$ crude fat $\mathrm{kg}^{-1} \mathrm{DM}$ were first defatted. The bags were submerged 3 times for $5 \mathrm{~min}$ in $250 \mathrm{ml}$ petroleum ether with initial and final agitation by pushing an inner beaker up and down, and were finally air-dried. The acid and basic solutions (2 l) were pre-heated to $95^{\circ} \mathrm{C}$ in the reaction vessel and after submerging the samples, brought to boiling point as soon as possible. Digestion times, 30 min for both steps, were measured from the moment the samples were put in the vessel. In contrast with the CT, no filtration aid and antifoam agent were added. After the first and the second digestion, samples were washed respectively two and three times for 5 min with 21 boiling water. During rinsing the samples stayed in the bag suspender and were agitated in the reaction vessel. After expelling the excess water, the bags were soaked in $350 \mathrm{ml}$ acetone for $3 \mathrm{~min}$ with 
similar agitation as described for the lipid extraction. The air-dried filter bags were completely dried for $4 \mathrm{~h}$ at $130^{\circ} \mathrm{C}$, and finally, incinerated for $2 \mathrm{~h}$ at $550^{\circ} \mathrm{C}$.

\section{Neutral detergent fibre}

NDF was determined in 10 feed samples with less than $100 \mathrm{~g} \mathrm{starch} \mathrm{kg}^{-1} \mathrm{DM}$ [compound feed (4), soyabcan mcal (2), formaldehyde treated soyabean meal, grass hay, grass silage, wheat straw] and 14 starchy feed samples [compound feed (8), maize silage (6)]. With the CT, the procedure of Van Soest and Wine (1967), including the addition of sodium sulphite, was followed. For feeds with more than $100 \mathrm{~g}$ starch $\mathrm{kg}^{-1} \mathrm{DM}, 50 \mu \mathrm{l}$ of a heat stable $\alpha$-amylase (A3306, Sigma-Aldrich Co., St. Louis, USA) was added to the solution (Van Soest et al., 1991). Samples with more than $100 \mathrm{~g}$ crude fat $\mathrm{kg}^{-1} \mathrm{DM}$ were previously defatted. Also, 2-cthoxyethanol was replaced by the safer triethylene glycol to facilitate the solubilisation of starch (Van Soest et al., 1991).

For the evaluation of the FBT, the conventional method was followed as well as possible. However, because of the batch extraction and the new concept of filtration, both decahydronaphtalene and sodium sulphite were omitted. One gram samples were weighed into the filter bags, defatted if necessary and then, after submerging in 21 preheated detergent solution $\left(95^{\circ} \mathrm{C}\right)$, brought to boiling point as soon as possible. After digestion for $60 \mathrm{~min}$, bags were washed 3 times for $5 \mathrm{~min}$ with boiling water and then, after removal of the free water, soaked in $350 \mathrm{ml}$ of acetone for 3 min with initial and final agitation. Finally, the air-dried filter bags were completely dricd for $8 \mathrm{~h}$ at $103^{\circ} \mathrm{C}$ and ashed for $2 \mathrm{~h}$ at $550^{\circ} \mathrm{C}$. NDF-values were corrected for ash content.

When starchy feed samples were analysed, $1 \mathrm{ml} \alpha$-amylase was added to the detergent solution at ambient temperature.

\section{Acid detergent fibre}

For ADF, the comparative study involved 11 feed samples: compound feed (2), lucerne meal, brewers' grains, dehydrated sugar beet pulp, grass hay, grass silage, maize silage, potatoes, soyabean meal and wheat straw. The procedure of Goering and Van Soest (1970) was followed, using a sample weight of one gram. Samples with more than $100 \mathrm{~g}$ crude fat $\mathrm{kg}^{-1} \mathrm{DM}$ were defatted. The results were calculated on an ash-free basis.

Sequential determination of NDF, ADF and lignin

Compared with the separate determination of NDF, ADF and lignin, the scquential fibre analysis allows a more cconomic usc of the sample, eliminates inter- 
ferences and results in a more accurate estimation of the hemicellulose and cellulose content (Van Soest et al., 1991). Using the CT, twelve feed samples [lucerne meal, compound fecd (5), ensiled brewers' grains, grass (2), maize cob silage, maize silage (2)] were analysed for NDF, ADF and lignin (ADL) by sequential extractions in neutral detergent, acid detergent and $72 \% \mathrm{H}_{2} \mathrm{SO}_{4}$ according to Van Socst et al. (1991). Sodium sulphite was omitted because of its delignifying action. With the FBT, $1.0 \mathrm{~g}$ samples were weighed into the filter bags for successive digestion in the neutral and acid detergent solution as described in the separate procedures, and including the addition of $\alpha$-amylase during the ND digestion. The bags with the ADF residue were soaked in a beaker with $350 \mathrm{ml} 72 \% \mathrm{H}_{2} \mathrm{SO}_{4}$ for $3 \mathrm{~h}$ with agitation every $30 \mathrm{~min}$. Then, the bags containing the ADL residue (Klason lignin) were rinsed with boiling water until neutral, underwent a cold extraction with acetone and were air-dried. Complete drying and finally the incineration were performed as described above.

\section{Statistical analysis}

The mean difference between the two techniques within a sample group was investigated with a two-tailed Student T-test. The repeatability was evaluated as within-sample variation by calculating the mean difference between the first two determinations. The relationship between the CT and FBT values was examined by means of linear regression.

\section{RESULTS AND DISCUSSION}

\section{Crude fibre}

In Table 1, the mean CF-content and mean difference between duplicates obtained with the $\mathrm{CT}$ and $\mathrm{FBT}$ as well as the regression equations between both techniques are given per category of sample. The FBT value, averaged for all feed samples was significantly $(\mathrm{P}<0.001)$ lower than the $\mathrm{CT}$ value, although the difference was small (138 vs $144 \mathrm{~g} \mathrm{~kg}^{-1} \mathrm{DM}$ ). For the separate feed categories also significant lower values were obtained with the FBT, except for the ruminant compound feeds. This is in contrast with Komarek et al. (1996), who found no significant differences and with Kuhla (1998), who obtained significantly higher values for the FBT than for the CT. The tendency of an increasing difference with higher CF-contents, as shown in Figure 1, can be explained by a more disturbed filtration in the $\mathrm{CT}$, when more organic residue remains in the crucible. Despite these differences both techniques were highly correlated $(r=0.996)$. The FBT was more repeatable than the $\mathrm{CT}$ for all feed categories. With the $\mathrm{CT}, 75 \%$ of the samples 
TABLE 1

The conventional technique (CT) versus the filter bag technique (FBT) for the determination of crude fibre $\left(\mathrm{g} \mathrm{kg}^{-1} \mathrm{DM}\right)$ in feeds and faeces

\begin{tabular}{|c|c|c|c|c|c|c|c|c|c|c|c|c|}
\hline \multirow{2}{*}{ Samples } & \multirow{2}{*}{$\mathrm{n}$} & \multirow{2}{*}{$\begin{array}{c}\text { Weight } \\
\mathrm{g}\end{array}$} & \multicolumn{2}{|c|}{$\mathrm{CT}$} & \multicolumn{3}{|c|}{ FBT } & \multicolumn{2}{|c|}{ Regression } & \multicolumn{3}{|c|}{$\mathrm{FBT}=\mathrm{a}^{*} \mathrm{CT}+\mathrm{b}$} \\
\hline & & & $\overline{\mathrm{X}} \pm \mathrm{sd}$ & $\overline{\mathrm{D}}^{\mathrm{i}} \pm \mathrm{sd}$ & $\overline{\mathrm{x}}$ & $\pm \mathrm{sd}$ & $\bar{D}^{i} \pm s d$ & a & $\pm \mathrm{sd}$ & & $\pm \mathrm{sd}$ & $\mathrm{r}^{\prime \prime}$ \\
\hline Forages & 21 & 1.0 & $235 \pm 74$ & $10 \pm 5$ & $227^{* *}$ & \pm 70 & $9 \pm 5$ & 0.938 & \pm 0.022 & 7.08 & \pm 5.45 & 0.995 \\
\hline Raw materials & 14 & 1.0 & $108 \pm 55$ & $7 \pm 4$ & $101 * * *$ & \pm 57 & $4 \pm 4$ & 1.032 & \pm 0.031 & -10.51 & \pm 3.74 & 0.994 \\
\hline Ruminant compounds & 11 & 1.0 & $101 \pm 16$ & $8 \pm 4$ & 98 & \pm 15 & $5 \pm 4$ & 0.772 & \pm 0.177 & 19.74 & \pm 18.19 & 0.823 \\
\hline Pig feeds & 10 & 1.0 & $53 \pm 11$ & $6 \pm 6$ & $46^{* *}$ & \pm 14 & $4 \pm 3$ & 1.065 & \pm 0.196 & -10.61 & \pm 10.57 & 0.887 \\
\hline All feeds & 56 & 1.0 & $144 \pm 90$ & $7 \pm 5$ & $138^{* * *}$ & \pm 89 & $5 \pm 5$ & 0.982 & \pm 0.011 & -3.82 & \pm 1.93 & 0.996 \\
\hline \multirow[t]{3}{*}{ Faeces } & 28 & 1.0 & $247 \pm 33$ & $12 \pm 7$ & 243 & \pm 30 & $20 \pm 13$ & 0.696 & \pm 0.114 & 70.90 & \pm 28.41 & 0.767 \\
\hline & 16 & 1.0 & $272 \pm 16$ & $12 \pm 8$ & $257^{* * *}$ & \pm 24 & $17 \pm 11$ & 1.327 & \pm 0.194 & -103.37 & \pm 52.77 & 0.877 \\
\hline & $16^{\mathrm{iii}}$ & 0.5 & & & $236^{* * *}$ & \pm 18 & $4 \pm 3$ & 1.020 & \pm 0.136 & -41.10 & \pm 37.03 & 0.894 \\
\hline
\end{tabular}

** $\mathrm{P}<0.01 ; * * * \mathrm{P}<0.001$

${ }^{i}$ the mean difference between the first two determinations

ii correlation coefficient

iii FBT - values for $0.5 \mathrm{~g}$ samples were compared with the CT - values of $1.0 \mathrm{~g}$ samples 
needed three or more determinations, whereas this was only necessary for $30 \%$ of the samples examined with the FBT.

For faeces samples, the difference between both techniques was not significant and was either positive or negative, resulting in a poor correlation (Table 1). Contrary to the feed samples, the repeatability was lower with the FBT. This was attributed to a decreased accessibility of the sample for the digestion solution, because one gram faeces per filter bag looked very voluminous. Therefore, the sample weight was reduced to $0.5 \mathrm{~g}$ for 16 of the 28 samples (only cattle faeces). As expected, the incubation of a smaller amount of sample in the bags improved the precision of the FBT. On the other hand, the reduced sample weight resulted in significantly $(\mathrm{P}<0.001)$ lower values, on average $36 \mathrm{~g} \mathrm{~kg}^{-1} \mathrm{DM}$, as compared with the CT. However, part of the difference could be explained by the selected samples, which also appeared to have a significantly lower mean CF-content with the

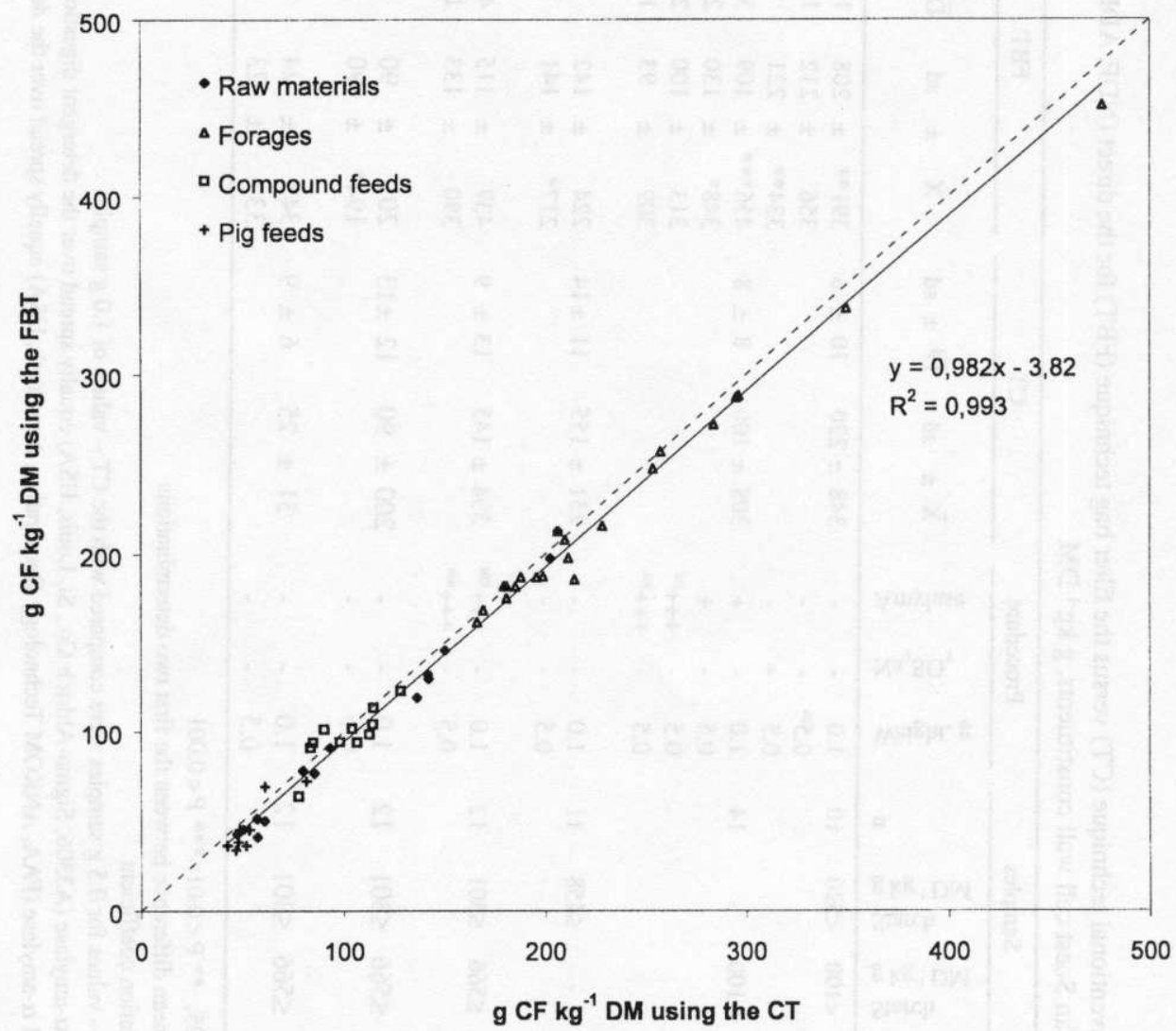

Figure 1. Relationship between the conventional (CT) and the filter bag technique (FBT) in determining the $\mathrm{CF}$ of 56 feed samples 
TABLE 2

The conventional technique (CT) versus the filter bag technique (FBT) for the direct (NDF, ADF) and sequential (NDF , and $\mathrm{ADL}_{\mathrm{s}}$ ) determination of the Van Soest cell wall constituents, $\mathrm{g} \mathrm{kg}^{-1} \mathrm{DM}$

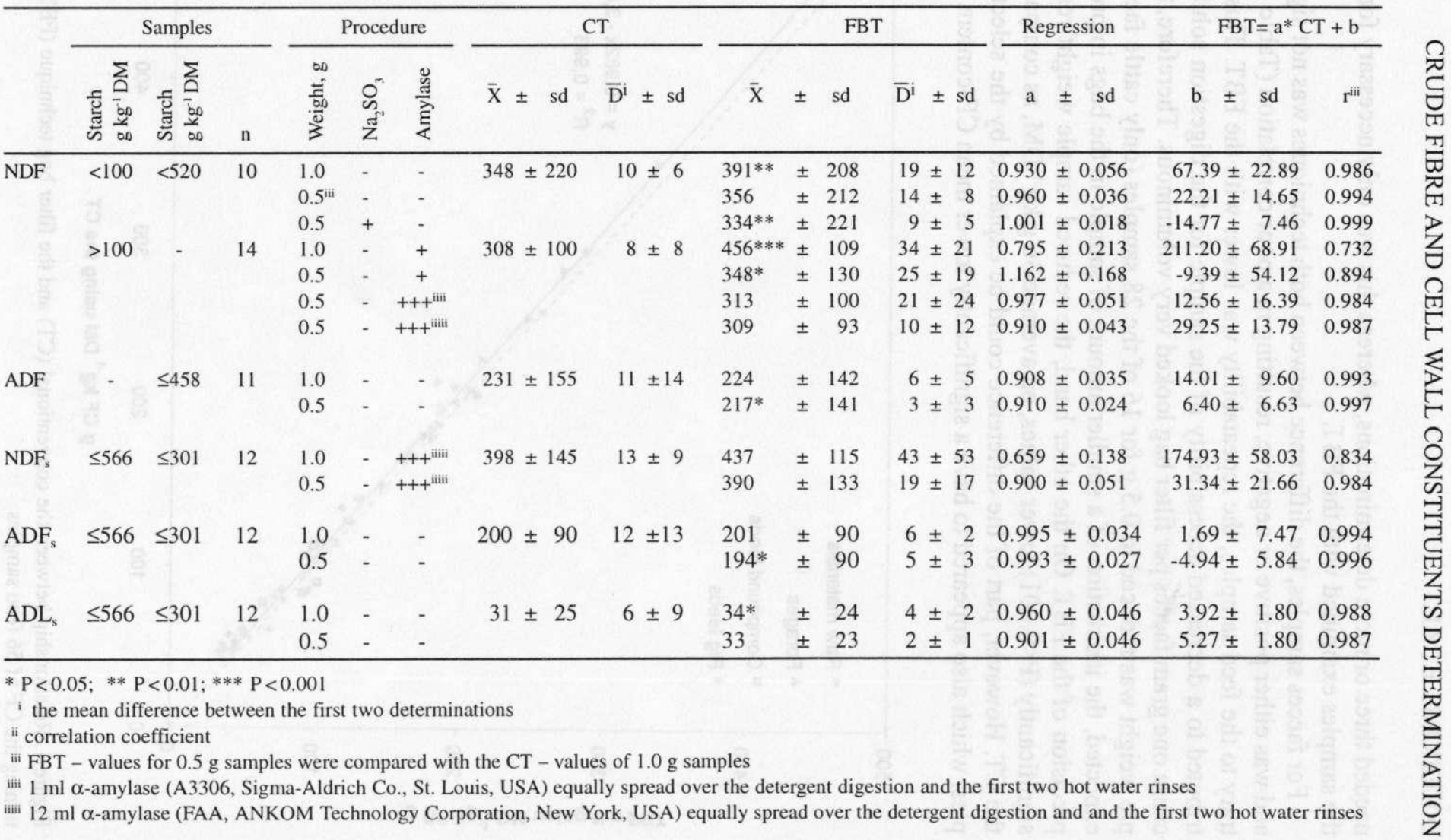


FBT, when a one gram sample was incubated. Probably, the values obtaincd with the $\mathrm{CT}$, are somewhat overestimated, because the relatively high sand content in faeces samples may disturb crucible filtration. This latter hypothesis may also explain the poor correlation between both techniques for the analysis of faeces samples (Table 1).

\section{Neutral detergent fibre}

The results of the NDF-analyses with the CT and the FBT are summarised for both starchy and non-starchy feeds in Table 2.

For the feed samples with less than $100 \mathrm{~g}$ starch $\mathrm{kg}^{-1} \mathrm{DM}$, significantly $(\mathrm{P}<0.01)$ more NDF was found with the FBT; on average $43 \mathrm{~g} \mathrm{~kg}^{-1} \mathrm{DM}$. This difference was particularly due to the formaldehyde treated soyabean meal and the 4 compound feeds. By halving the sample weight in the filter bags, the difference between the two techniques was no longer significant, except for the treated meal. Obviously, the formaldehyde treatment inhibited an efficient solubilisation of the protcins in the FBT. Without this sample, and over a wide range of protein content $(22-480 \mathrm{~g}$

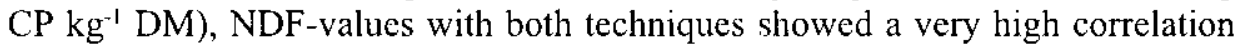
$(\mathrm{r}=0.999)$. Reducing the sample weight in the FBT also improved repeatability, although it was still lower compared with the CT. This latter is not in agreement with the findings of Spanghero et al. (1997), who obtained a better repcatability with the FBT for non-starchy forages.

Addition of sodium sulphite in the reaction vessel $(0.5 \mathrm{~g} / 100 \mathrm{ml}$ detergent solution) increased repeatability to a similar level as with the CT and resulted in an acceptable NDF value for the formaldehyde treated soyabean meal. Howcver, this treatment also significantly $(\mathrm{P}<0.001)$ lowered the NDF content of the other feeds compared with the CT. These findings agrec with earlier reports that sodium sulphite lowers fibre estimations (Robertson and Van Socst, 1990; Hintz et al., 1996) and positively affects reproducibility (Hintz et al., 1996). However, because it is known that sodium sulphite attacks lignin and cleaves disulphide bonds, which are both non-biological actions (Van Soest et al., 1991), and it hardly aids the filtration, its addition is not recommended.

For most starchy feeds, crroneously high NDF-values were found when $1.0 \mathrm{~g}$ samples were incubated in the bags (Table 2). Neither by increasing the amount of $\alpha$-amylase in the reaction vessel (results not shown), nor by reducing the size of the feed sample similar NDF-values for FBT and CT could be obtained. However, the overestimation remaining after halving the sample weight, on average $40 \mathrm{~g} \mathrm{~kg}^{-1} \mathrm{DM}$, could mainly be ascribed to four samples high in rumen undegradable starch. By equally spreading the amount of $\alpha$-amylase (A3306, Sigma-Aldrich Co., St. Louis, USA) over the neutral detergent digestion and the first two hot water rinses, the accuracy improved but not the precision. The within-sample variation could well be lowered to a level comparable with the CT, when $12 \mathrm{ml}$ of 
a less concentrated $\alpha$-amylase solution (FAA, ANKOM Technology Corporation, New York, USA) was added in three times. Pooling the results of the starchy and non-starchy samples resulted in a good correlation $(r=0.992)$ between the FBT and CT (Figure 2).

Because the FBT appears very sensitive to starch interference, the addition of $\alpha$-amylase might be necessary even at a lower starch content than $100 \mathrm{~g} \mathrm{~kg}^{-1} \mathrm{DM}$. For 28 nylon bag residues of compound feeds, obtained after rumen incubation, the differences between the NDF-values from FBT with or without the addition of $\alpha$-amylase (FAA, ANKOM Technology Corporation, New York, USA), are shown

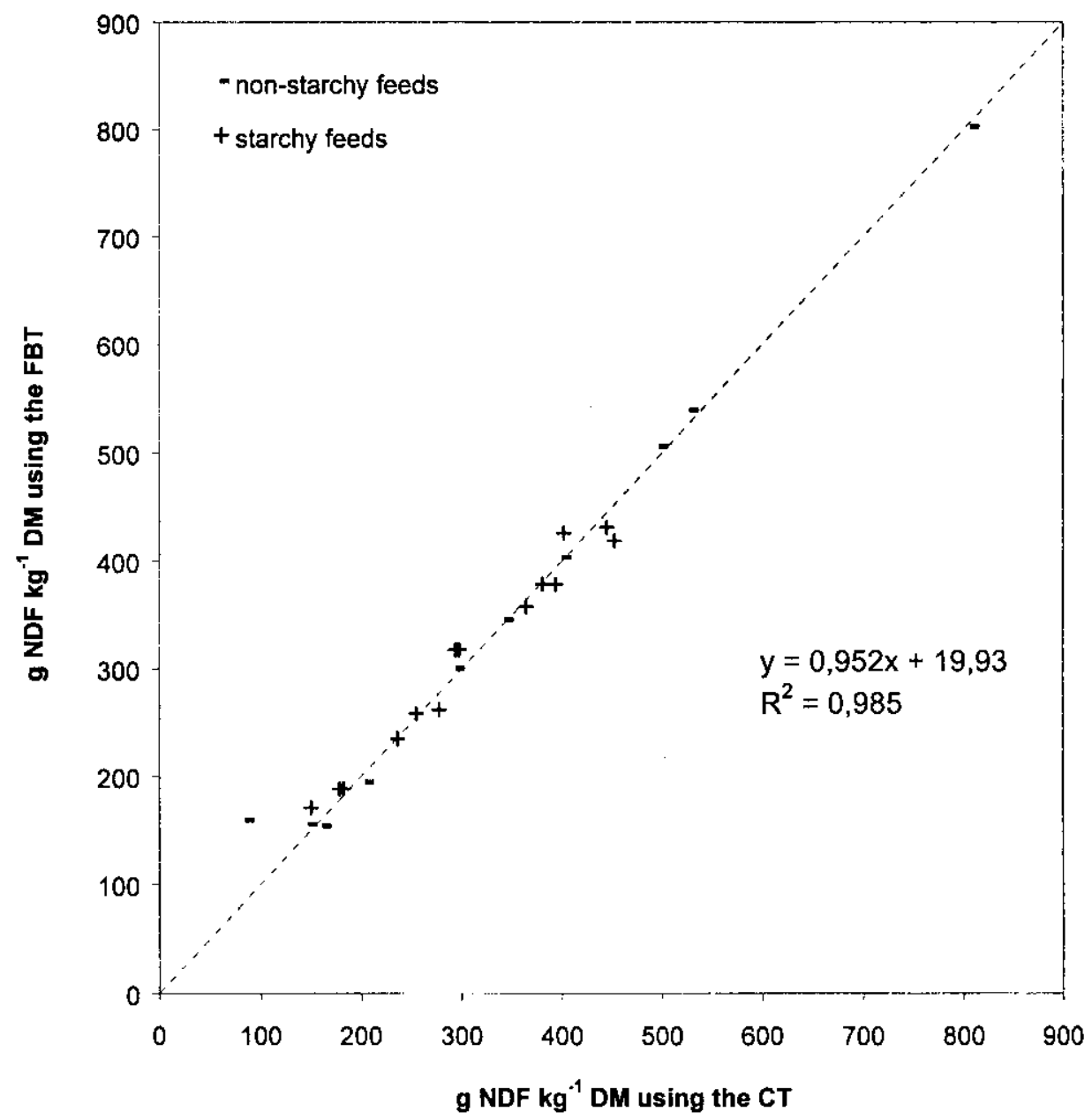

Figure 2. Relationship between the conventional (CT) and the filter bag technique (FBT) in determining NDF of 10 non-starchy and 14 starchy feed samples 
in relation to their starch content $\left(15-99 \mathrm{~g} \mathrm{~kg}^{-1} \mathrm{DM}\right)$ in Figure 3. Despite the poor correlation $(r=0.791)$ the addition of $\alpha$-amylase tended to be effective for starch contents above $25 \mathrm{~g} \mathrm{~kg}^{-1} \mathrm{DM}$. Therefore the addition of $\alpha$-amylase is recommended for any starch containing sample.

Acid detergent fibre

When one gram samples were analysed for ADF, the mean FBT value was not significantly lower than the CT valuc (224 vs $231 \mathrm{~g} \mathrm{~kg}^{-1} \mathrm{DM}$; Table 2). However, the difference between both techniques showed a large variation, because with the FBT higher values were found for soyabean meal and brewers' grains, while lower values for most of the other feeds. Contrary to earlier findings of Spanghero et al. (1997) and over a wide range of CP content (23-458 $\left.\mathrm{g} \mathrm{CP} \mathrm{kg}^{-1} \mathrm{DM}\right)$, the within-sample variation with the FBT was nearly half that with the CT. Halving the sample weight with the FBT resulted in a still better repeatability and improved the correlation with the CT $(r=0.997)$. Although the ADF values with the

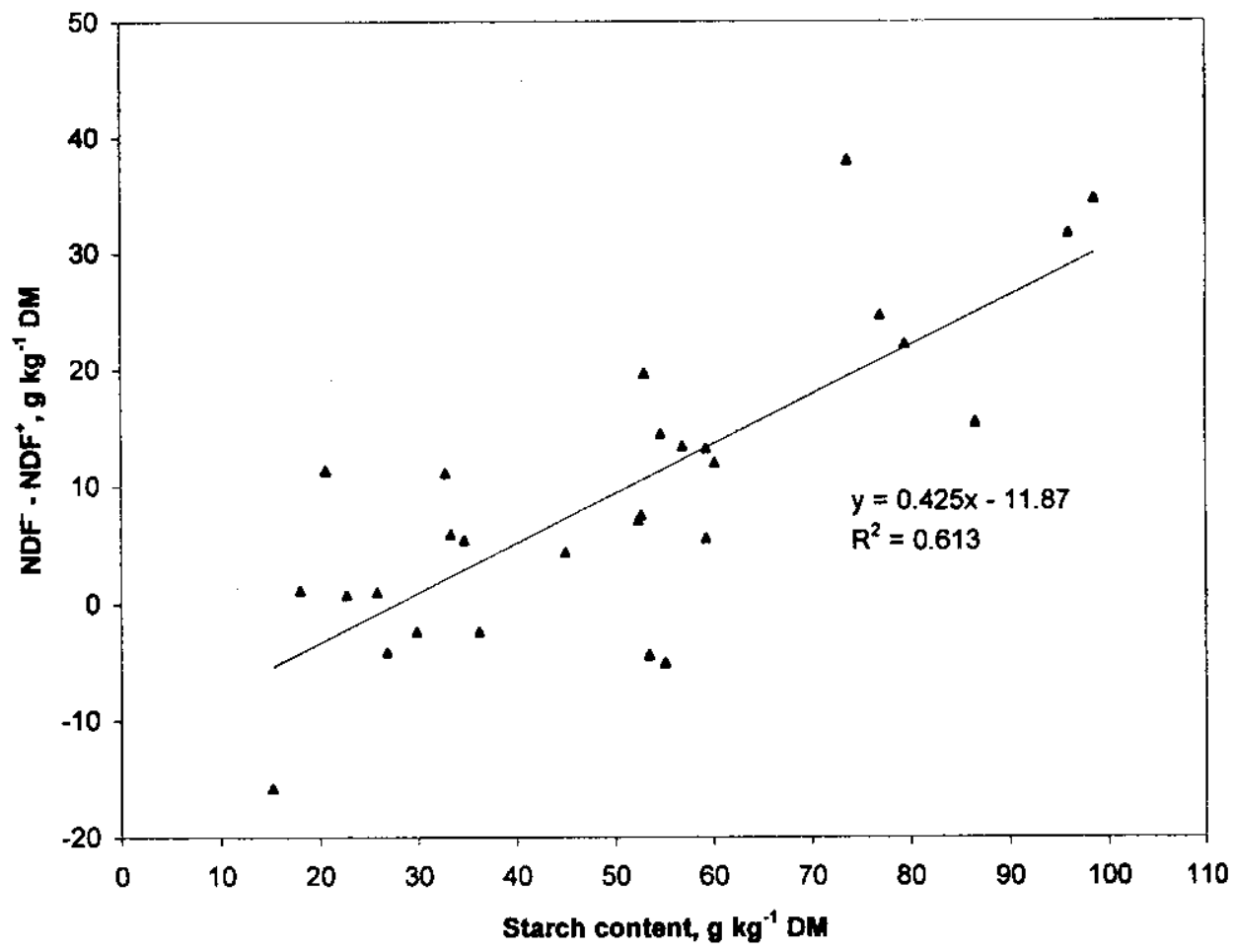

Figure 3. The difference between the NDF detemination with $\left(\mathrm{NDF}^{+}\right)$or without (NDF') the addition of $\alpha$-amylase for 28 nylon bag residues in relation to their starch content 
FBT were significantly lower than with the CT, the average difference of $14 \mathrm{~g} \mathrm{~kg}^{-1}$ $\mathrm{DM}$, is considerated to be of concern and should be ascribed to the more optimal filtration with the filter bags.

\section{Sequential analysis of NDF, ADF and lignin}

The results of the sequential analysis $\left(\mathrm{NDF}_{\mathrm{s}}, \mathrm{ADF}_{\mathrm{s}}\right.$ and $\mathrm{ADL}_{\mathrm{s}}$ ) are given in Table 2 for one as well as for $0.5 \mathrm{~g}$ samples. For NDF, the results with FBT were again clearly bettcr with $0.5 \mathrm{~g}$ than with $1.0 \mathrm{~g}$ samples. The rather bad repeatability with the former sample weight was particularly due to the presence of a starchy maize cob silage in the sample set. Omitting this sample resulted in significantly lower $(\mathrm{P}<0.05)$ and better repeatable $(\mathrm{D}=16 \pm 16)$ NDF values for the FBT analysis as well as in a better correlation ( $\mathrm{r}=0.995)$. With a reduced sample weight of $0.5 \mathrm{~g}$, also significantly $(\mathrm{P}<0.05)$ lower FBT values were obtained for ADF (194 vs $200 \mathrm{~g} \mathrm{~kg}^{-1} \mathrm{DM}$ ), whereas for ADL similar values were obtained. For both ADF and ADL repeatability was greatly improved with the FBT.

\section{CONCLUSIONS}

The analysis of CF, ADF and ADL is more accurate and better repeatable than with the $\mathrm{CT}$, because of the more optimal filtration. The somewhat lower repeatability of NDF analysis with the FBT can be ascribed to its higher sensitivity for starch interference. Nevertheless, together with the practical (higher capacity, savings in labour and time) and financial (lower purchase price and cost of maintenance) benefits, the analytical advantages make the FBT an attractive alternative for the CT.

\section{REFERENCES}

De Boever J.L.. Cottyn B.G., De Brabander D.L., Vanacker J.M., Boucqué Ch.V., 1996. Prediction of the feeding value of grass silages by chemical parameters, in vitro digestibility and NIRS. Anim. Feed Sci. Tech. 60, 103-115

De Boever J.L., Cottyn B.G., De Brabander D.L., Vanacker J.M., Boucqué Ch.V., 1997. Prediction of the feeding valuc of maize silages by chemical parameters, in vitro digestibility and NIRS. Anim. Feed. Sci. Tech. 66. 211-222

De Brabander D.L., Andries J.I., De Boever J.L., Buysse F.X., 1987. Alimentation économique pour vaches laitic̀res en utilisant de meilleurs fourrages grossiers. Publication No 684, Agricultural Research Centre - Department Animal Nutrition and Husbandry, Melle (Belgium), pp.1-26

De Brabander D.L., De Smet A.M., Vanacker J.M., Boucqué Ch.V., 1996. Contribution to a physical structure value system for dairy cattle. In: J.A.M. Van Arendonk (Editor). Book Abstracts of $47^{\text {th }}$ 
Annual Meeting of European Association of Animal Production. Wageningen Press, Wageningen (The Netherlands), p. 74

EC, 1992. Determination of Crude Fibre. Directive $n^{\circ}$ L 344/36 of the Commission of the European Communities of 26.11.92. Offic. J. Eur. Com., Brussels (Belgium)

Goering H.K., Van Soest P.J., 1970. Forage Fiber Analyses (Apparatus, Reagents, Procedures and some Applications). Agricultural Handbook No. 379. ARS, USDA, Jacket No. 387-598, Washington, DC

Hintz. R.W., Mertens D.R., Albrecht K.A., 1996. Effects of sodium sulfite on recovery and composition of detergent fibre and lignin. J. Assoc. Off. Anal. Chem. Int. 79, 16-22

Jung H.G., Allen M.S., 1995. Characteristics of plant cell walls affecting intake and digestibility of forages by ruminants. J. Anim. Sci. 73, 2774-2790

Komarck A.R., 1993. An improved filtering technique for the analysis of neutral detergent fiber and acid detergent fiber utilizing the filter bag technique. Publication No 101, ANKOM Company, Fairport, NY, pp. 1-10

Komarek A.R., Manson H., Thiex N., 1996. Crude fiber determinations using the ANKOM fiber system. Publication Nol02, ANKOM Technology Corporation, Fairport. NY, pp. 1-4

Komarek A.R., Robertson J.B., Van Soest P.J., 1994a. A comparison of methods for determining ADF using the filter bag technique versus conventional filtration. J. Dairy Sci. 77, Suppl. 1. 33

Komarek A.R., Robertson J.B., Van Soest P.J., 1994b. Comparison of the filter bag technique to conventional filtration in the Van Soest NDF analysis of 21 feeds. Proceedings of National Conference on Forage Quality, Evaluation and Utilization. University of Nebraska, p. 1

Kuhla S., 1998. Zur Problematik der Rohfaserbestimmung in Futtermitteln, Digesta und Fäzes. In: P. Junghans, M. Beyer, W. Hackl (Editors). International Symposium on Energetic Feed Evaluation and Regulation of Nutrient and Energy Metabolism in Farm Animals. Schriftenreihe Noll. Forschungsinstitut für die Biologie Landwirtschaflichen Nutztiere, Rostock (Germany)

Robertson J.B., Van Soest P.J., 1990. The detergent system of analysis and its application to human foods. In: W.P.T. James, O. Theander (Editors). The Analysis of Dietary Fibre in Food. Marcel Dekker, New York, pp. 123-158

Spanghero M., Moscardini S., Susmel P., Stefanon B., Lavrencic A., 1997. A comparison between two systems for NDF and ADF analysis. J. Dairy Sci. 80, Suppl. 1, 260 (Abstr. P452)

Van Soest P.J., Mertens D.R., Deinum B., 1978. Preharvest factors influencing quality of conserved foragc. J. Anim. Sci. 47, 712-720

Van Soest P.J., Robertson J.B., 1980. Systems of analysis for evaluating fibrous feeds. In: W.J. Pigden, C.C. Balch, M. Graham (Editors). Standardisation of Analytical Methodology for Feeds. Proceedings of a Workshop, Ottawa (Canada), pp. 49-60

Van Soest P.J., Robertson J.B., Lewis B.A., 1991. Methods for dietary fiber, neutral detergent fiber, and nonstarch polysaccharides in relation to animal nutrition. J Dairy Sci. 74, 3583-3597

Van Soest P.J., Wine R.H., 1967. Use of detergents in the analysis of fibrous feeds. IV. Detcrmination of plant cell-wall constituents. J. Assoc. Off, Anal. Chem. 50, 50-55 


\section{STRESZCZENIE}

Porównanie wyników oznaczania włókna surowego i składników ścian komórkowych wedlug Van Soest'a oznaczonych przy użyciu woreczków filtracyjnych lub filtrów konwencjonalnych

Porównano wyniki analizy włókna surowego (CF), NDF, ADF i ADL oznaczonych metodą konwencjonalną (CT) używając do sączenia tygli filtracyjnych lub techniką sączenia w woreczkach filtracyjnych (FBT). Średnia zawartość CF w 56 paszach objętościowych metodą FBT była nieco mniejsza niż oznaczone metodą CT (144 vs $138 \mathrm{~g} \mathrm{~kg}^{-1} \mathrm{SM}$ ), ale różnice okazały się statystycznie istotne $(\mathrm{P}<0,001)$. Wyniki otrzymane obydwiema metodami były wysoce skorelowane $(0,996)$, ale metoda FBT dawała lepszą powtarzalność wyników. Średnia zawartość CF w 28 próbach kału, oznaczona dwiema metodami była podobna, jednakże powtarzalność wyników otrzymanych metodą FBT była gorsza, ale można ją było poprawić przez zmnicjszenie wielkości naważki próby branej do analizy z 1,0 do $0,5 \mathrm{~g}$. NDF oznaczano w 10 paszach nie zawicrających skrobi, 14 paszach skrobiowych oraz w 28 pozostałościach po trawieniu pasz w żwaczu metodą in sacco. W celu otrzymania podobnych wyników obydwiema metodami zaleca się naważkę prób do analizy $0,5 \mathrm{~g}$ i dodawanie do prób zawierających skrobię $12 \mathrm{ml}$ roztworu $\alpha$-amylazy rozprowadzonej równomiernie na czas trawienia i pierwszych dwóch okresach płukania. Korclacja wyników zawartości ADF w 11 paszach poprawiła się z 0,993 do 0,997 , gdy próbę do analizy zmnicjszono z 1,0 do $0,5 \mathrm{~g}$; powtarzalność wyników była lepsza przy oznaczaniu FBT. Wyniki zawartości ADL w 12 paszach, po sekwencyjnej analizie NDF i ADF, otrzymane metodą FBT wykazały wysoką precyzję oznaczeń, i nie różniły się one od otrzymanych metodą CT. 